\title{
Assessment of groundwater potential zones using GIS and AHP techniques: a case study of the Lafia district, Nasarawa State, Nigeria
}

\author{
Stanley Ikenna Ifediegwu ${ }^{1}$ (i)
}

Received: 30 March 2020 / Accepted: 10 December 2021 / Published online: 21 December 2021

(c) The Author(s) 2021

\begin{abstract}
In the Lafia district, rising population has increased the need for groundwater resources for economic growth. Sustainable groundwater resource management demands accurate quantitative assessment, which may be accomplished using scientific theories and innovative methods. In present study, an integrated method has been employed to assess the groundwater potential zones in the Lafia district utilizing remote sensing (RS), geographic information system (GIS), and analytic hierarchy method (AHP). For this aim, eight thematic maps regulating to occurrence and transportation of groundwater (i.e., geology, rainfall, geomorphology, slope, drainage density, soil, land use/land cover and lineament density) were generated and converted into raster format utilizing ArcGIS tool. Weights were assigned to these eight thematic maps based on their importance. Moreover, the final normalized weights of these parameters were calculated adopting pairwise comparison matrix of the AHP. To create the groundwater potential zones (GWPZs) map of the research area, we employed the overlay weighted sum approach to combine the parameters. The map has been divided into four zones (good, moderate, poor and very poor), each of which represents 19.3, 12.9, 57.8, and 10\% of the study area. Lastly, the GWPZs map was validated utilizing borehole data obtained from 50 wells scattered throughout the study area to examine the performance of the approach. The validation results demonstrate that the adopted procedure produces highly reliable results that can aid in long-term development and strategic use of groundwater resources in this area.
\end{abstract}

Keywords AHP · Lafia $\cdot$ GIS environment $\cdot$ Weighted overlay analysis $\cdot$ Groundwater potential zone

\section{Introduction}

Globally, one-third of total freshwater abstractions come from groundwater (Das et al. 2018). It is a vital natural asset for any economic and social development in many parts of the world where water supplies are scarce (Kordestani et al. 2019). All economic activities are intrinsically and extrinsically relied on groundwater supplies. Nevertheless, underlying geology, intensity of chemical weathering, recharge efficiency, groundwater level, and some surface element origins and among other factors, have a significant impact on this resource, while surface water is generally influenced by surface pollution (Y1ldırım 2021). Surface water, by definition, has a lower mineral composition than groundwater due to its proximity to the surface. It is extremely

Stanley Ikenna Ifediegwu

ifestanley11@gmail.com

1 Department of Geology, Faculty of Physical Sciences, University of Nigeria, P.M.B. 410001, Nsukka, Nigeria vulnerable to contamination resulting from human activities (Gbosh et al. 2020). Furthermore, building of surface water extraction devices for various uses are more expensive and it covers a bigger area than groundwater sites. As a result of all these benefits, the groundwater needs for household, agricultural, commercial and other uses is escalating year after year (Thapa et al. 2017). The desire for groundwater in nations like Nigeria is increasing as a result of rapid population expansion, urbanization, and the country's economic advancement. In the current study region, groundwater is also the most prevalent resource used for potable water supply, farming, and animal husbandries.

Groundwater investigation approaches that rely on geophysical technologies are both costly and time-consuming (Gnanachandrasamy et al. 2018; Lakshmi and Reddy 2018; Kwami et al. 2019). Due to these issues, people have been compelled to turn to various technologies that can aid them study big regions in a short space of time while working with little resources. These approaches, comprising GIS and remote sensing, have been used to identify groundwater 
potential zones. It is a simple and quick approach for exploring the groundwater potential zone in various geological settings (Thapa et al. 2017; Ifediegwu et al. 2019; Kanagaraj et al. 2019; Igwe et al. 2020). Several scholars have employed the RS and GIS procedures to designate groundwater potential zones all over the world (Allafta et al. 2021; Aju et al. 2021; Aykut 2021; Karimi and Zeinivand 2021; Qadir et al. 2020; Gyeltshen et al. 2020; Ahmad et al. 2020; Barhanu and Hatiye 2020; Gebru et al. 2020; Zghibi et al. 2020; Shao et al. 2020; Achu et al. 2019). Geology, geomorphology, slope, soil type, rainfall, land use/land cover, lineament structures and drainage criteria all play a role in discovering and exploring groundwater resources employing RS and GIS (Hamdani and Baali 2020; Lentswe and Molwalefhe 2020). The ability to locate the groundwater potential zone is critical for long-term resource management. It assists planners, decision-makers, and policymakers in ensuring that the groundwater resource is protected from both quantity and quality influences. Among the most widely utilized multi-criteria decision-making methods is the analytic hierarchy process (AHP) (Aliabad et al. 2018). AHP can be utilized to demarcate groundwater potential zones since it is a straightforward, simple, efficient, and dependable method (Igwe et al. 2020; Aju et al. 2021). The unification of GIS and AHP allows data to be converted into useful information for managers and policymakers (Guru et al. 2017). As a result, the purpose of this research is to use GIS and AHP to identify the GWPZs of the Lafia district, Nasarawa State. For this reason, eight thematic layers (i.e., geology, rainfall, geomorphology, slope, drainage density, soil type, land use/land cover and lineament density) were used in the assessment. This research will be a valuable asset for groundwater resources planners and policy makers when it comes to developing sustainable groundwater strategies in this district.

\section{Study area}

District of Lafia, located in the eastern part of Nasarawa State, Nigeria, surrounded by Wamba in the north, Nasarawa in the west, Obi in the south and Plateau State in the east (Fig. 1). The study area falls within latitudes $8^{\circ} 16^{\prime} 00^{\prime \prime} \mathrm{N}$ and $9^{\circ} 11^{\prime} 00^{\prime \prime} \mathrm{N}$ and longitudes $8^{\circ} 16^{\prime} 00^{\prime \prime} \mathrm{E}$ and $9^{\circ} 20^{\prime} 00^{\prime \prime} \mathrm{E}$ with areal extent of 1010 sq.km.

Lafia district generally has an undulating terrain with such a small hill toward the West-South and North-East.

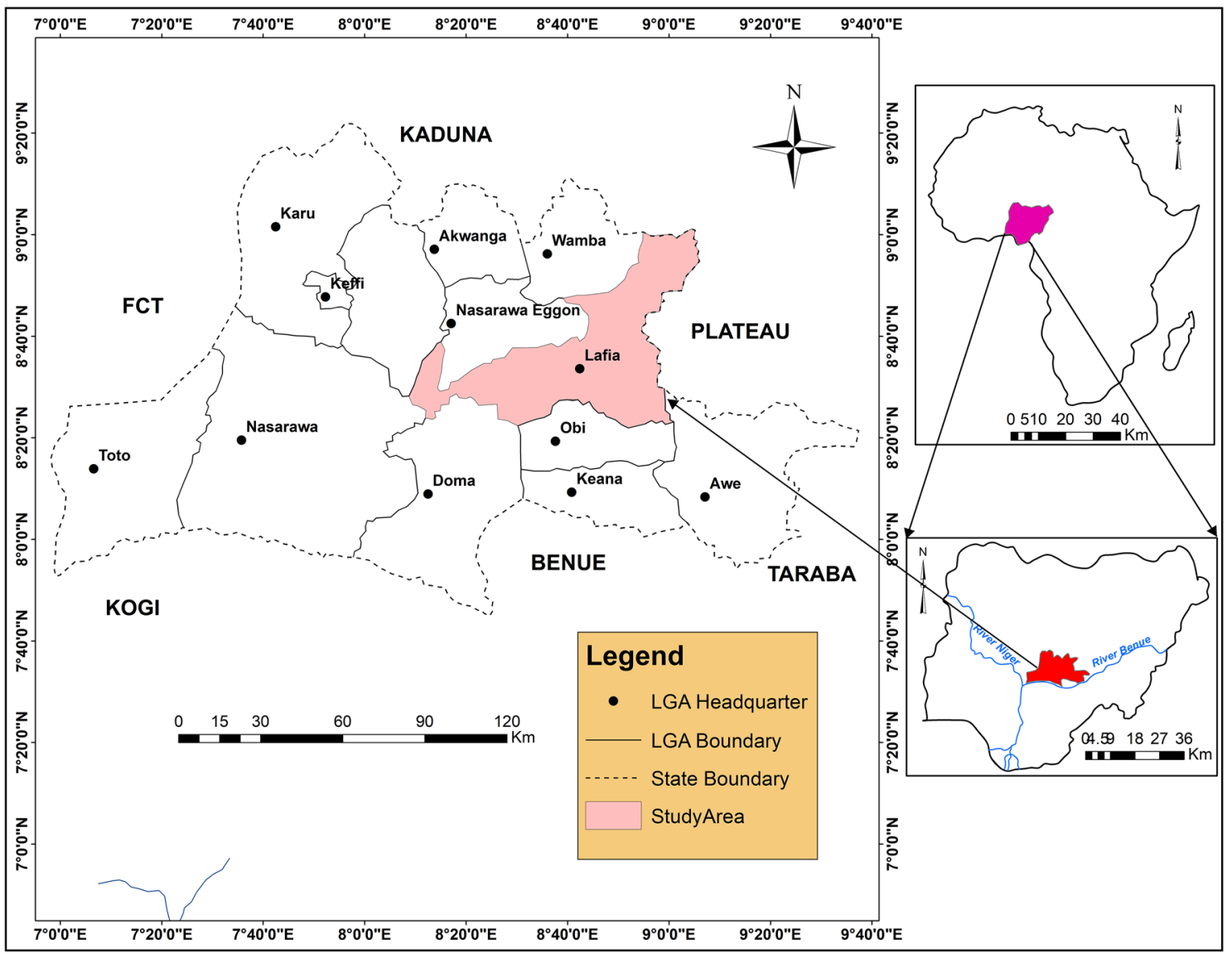

Fig. 1 Location map of the study area 
This region contains few large and small disconnected hills, they are: Konakancae, Monkwar, Shishem and Ngolo hills which are located along the north-eastern district boundaries. Much of the district of Lafia is drained by the Gwayaka and Mada Rivers which flows from north to south along the western and eastern district boundaries. Feferuwa, Ntirim, Rafin Gora, Lange, Ehula and Agbabija are the vital rivulets and tributaries to the Gwayaka and Mada Rivers. The rivers Feferuwa, Ntirim and Rafin Gora are draining in the eastern section of the district and the river Lange, Ehula and Agbabija drains in the western region of the district. The drainage pattern is dendritic (Fig. 2) which shows the geomorphic and geological homogeneity of the area. The drainage is structurally influenced and majority of the streams are seasonal and flow in distinct directions.

Throughout the year and two seasons the research area experiences relatively warm tropical weather with fairly high temperatures. Temperatures are generally high all year round due to tropical weather conditions with an average monthly value of around $27.5^{\circ} \mathrm{C}$, depending on the location and time of year, the maximum daytime temperatures range from 25 to $30{ }^{\circ} \mathrm{C}$ (Iloeje 1981). The weather season is defined by a lengthy-wet season during late-March and July, accompanied by torrential rains and dry weather preceded by a minimal dry season between late July to August and a brief-wet season (September-October) before dry season starts in November (Iloeje 1981). A study of the rainfall data from twelve stations over the 10 -year period revealed that the average yearly rainfall across the region ranges from about $1534.6 \mathrm{~mm}$ to $1685.4 \mathrm{~mm}$. Nevertheless, within the rainy months of April-September, around $80 \%$ of the rainfall falls (Iloeje 1981).

\section{Materials and methods}

\section{Choosing the parameters that affect groundwater storage potential}

Groundwater occurrence and movement are primarily governed by underlying lithology, landform, soil characteristics, lineament and drainage densities, while recharge is regulated by precipitation, land use/land cover type, and rate of penetration (Shao et al. 2020). Groundwater potentiality modeling can be accomplished by looking at the elements that govern groundwater flow, storage, and occurrence (Yildırım

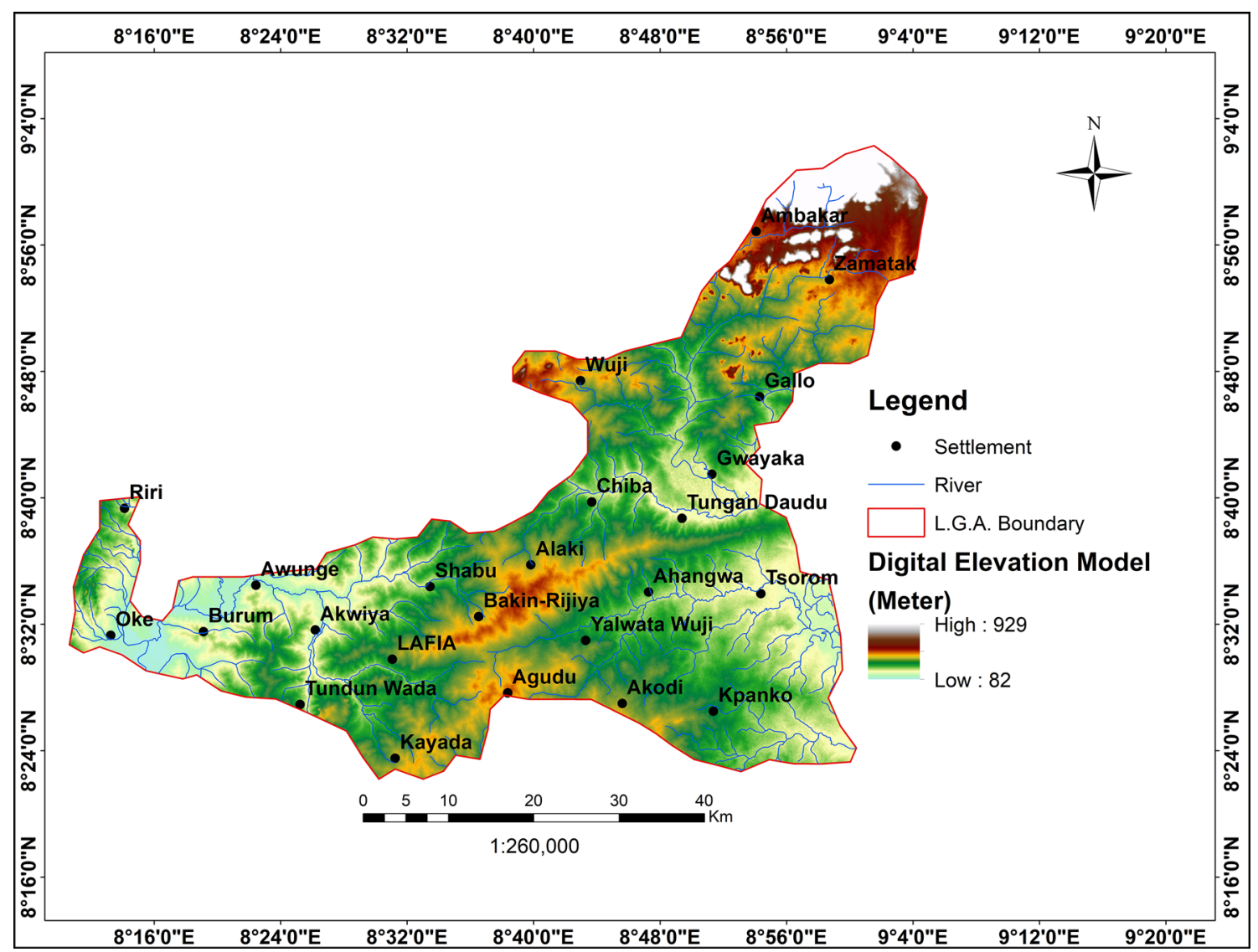

Fig. 2 DEM map of the study area 
2021; Ifediegwu et al. 2019). The present study generated and combined eight thematic layers (slope, drainage density, land use/land cover, rainfall, soil properties, geology, geomorphologic and lineament density) to produce a groundwater potential zones map utilizing ArcGIS 10.5.

software. The entire map themes were displayed in UTM Projection Zone 31, Datum WGS84, with a precision of $30 \mathrm{~m}$. All of the vector layers obtained were converted to raster format, which consisted of cells $20 \times 20 \mathrm{~m}$ in size. Figure 3 depicts the methods used to generate the GIS data layers and groundwater potential zones (GWPZs) map.

\section{Data collection and integration into a geographic information system (GIS) database}

The key data sources in this study were existing/analog geology, soil, and lineament maps, satellite images, and meteorological data measured at stations throughout the study area. The eight thematic maps (slope, geomorphology, drainage density, lithology, lineament density, rainfall, soil type, and land-use classes) required to generate the GWPZs map were produced in a GIS platform (ArcGIS 10.5 software) with the appropriate modifications using these key data sets.

The geology and soil map of the research area was extracted from Nigerian Geological Survey Agency and Soil Unit FAO/UNESCO/ISRIC map of Nigeria from which thematic layer maps were produced employing ArcGIS 10.5. However, lineaments in the research area were derived manually from lineament map of Nigeria collected from Nigeria Geological Survey Agency. Subsequently, the lineament density layer was produced, adopting the line density approach in the spatial analyst tool utilizing Eq. (1).

$$
\mathrm{Ld}=\sum_{i=1}^{n} \frac{L_{i}}{A}
$$

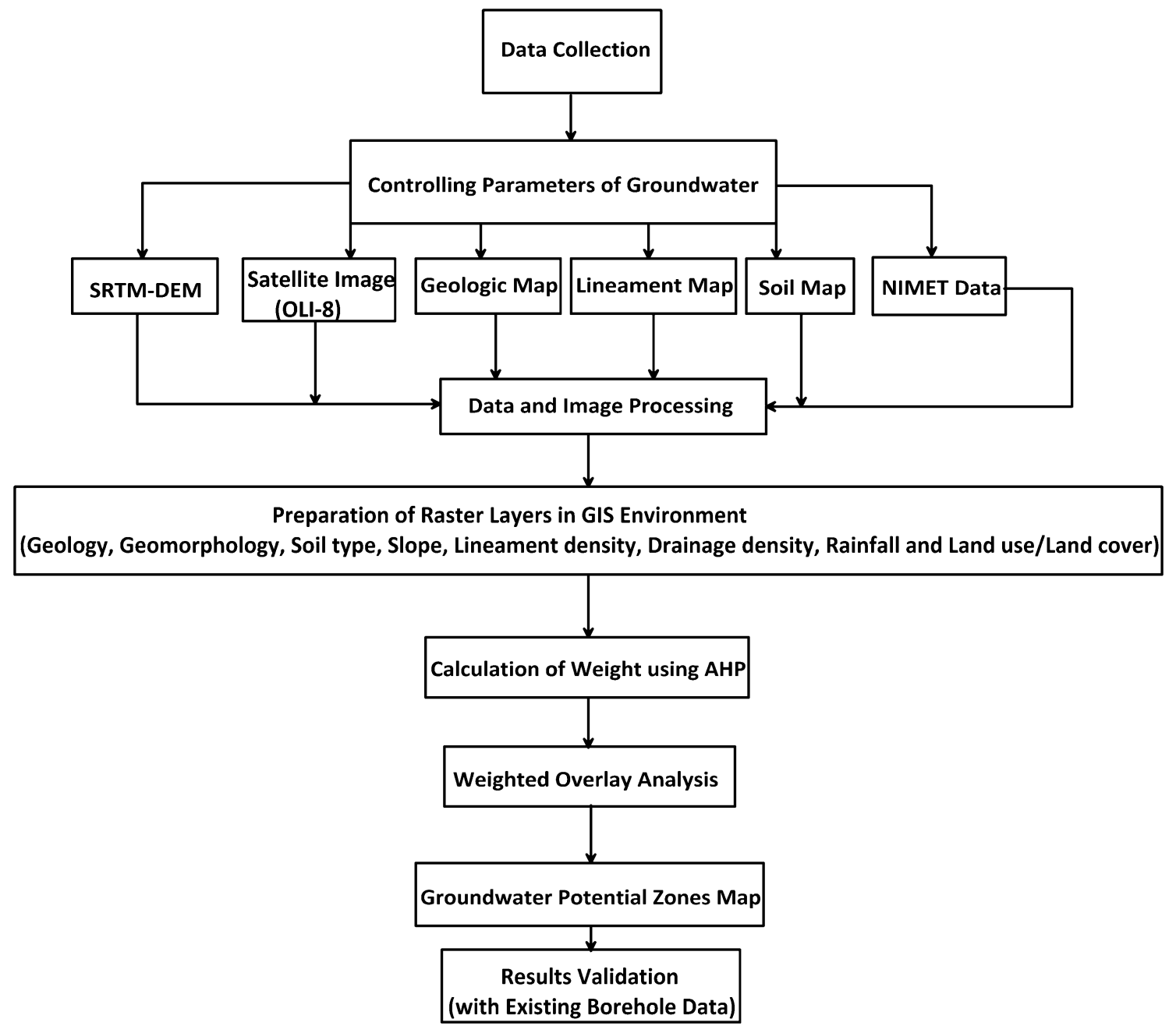

Fig. 3 Flowchart for characterizing potential zones of groundwater in the study area utilizing RS, GIS and AHP approaches 
Table 1 Constant rating scale of Saaty's AHP (Saaty 1990)

\begin{tabular}{|c|c|c|c|c|c|c|c|c|}
\hline \multicolumn{4}{|c|}{ Less influential } & \multirow{2}{*}{$\begin{array}{l}\text { Equally influ- } \\
\text { ential } \\
\text { Equal impor- } \\
\text { tance }\end{array}$} & \multicolumn{4}{|c|}{ More influential } \\
\hline $\begin{array}{l}\text { Extreme } \\
\text { importance }\end{array}$ & $\begin{array}{l}\text { Very strong } \\
\text { importance }\end{array}$ & $\begin{array}{l}\text { Strong impor- } \\
\text { tance }\end{array}$ & $\begin{array}{l}\text { Moderate } \\
\text { importance }\end{array}$ & & $\begin{array}{l}\text { Moderate } \\
\text { importance }\end{array}$ & $\begin{array}{l}\text { Strong impor- } \\
\text { tance }\end{array}$ & $\begin{array}{l}\text { Very strong } \\
\text { importance }\end{array}$ & $\begin{array}{l}\text { Extreme } \\
\text { importance }\end{array}$ \\
\hline $1 / 9$ & $1 / 7$ & $1 / 5$ & $1 / 3$ & 1 & 3 & 5 & 7 & 9 \\
\hline
\end{tabular}

2, 4, 6 and 8 are intermediate values that denotes comprise

Table 2 The RI ratio of the distinct values of $n$ (Saaty 1990)

\begin{tabular}{lllllllllll}
\hline $\mathrm{N}$ & 1 & 2 & 3 & 4 & 5 & 6 & 7 & 8 & 9 & 10 \\
\hline$R I$ & 0.00 & 0.00 & 0.58 & 0.89 & 1.12 & 1.25 & 1.32 & 1.40 & 1.45 & 1.49 \\
\hline
\end{tabular}

Table 3 The pair-wise comparison matrices and normalized weight $\left(w_{i}\right)$ of the different themes

\begin{tabular}{|c|c|c|c|c|c|c|c|c|c|c|}
\hline Themes & GG & GM & ST & SL & LD & DD & RF & LULC & $\begin{array}{l}\text { Allo- } \\
\text { cated } \\
\text { weight }\end{array}$ & $\begin{array}{l}\text { Normalized } \\
\text { weight }\left(w_{i}\right)\end{array}$ \\
\hline Geology (GG) & 1 & & & & & & & & 8 & 0.1814 \\
\hline Geomorphology (GM) & 1.4 & 1 & & & & & & & 7 & 0.1581 \\
\hline Soil Type (ST) & 1.3 & 1.6 & 1 & & & & & & 6 & 0.1232 \\
\hline Slope (SL) & 1.5 & 1.2 & 1.3 & 1 & & & & & 5 & 0.1121 \\
\hline Lineament density (LD) & 1.1 & 1.5 & 1.4 & 1.2 & 1 & & & & 4 & 0.0970 \\
\hline Drainage density (DD) & 1.2 & 1.3 & 1.1 & 1.6 & 1.3 & 1 & & & 3 & 0.0694 \\
\hline Rainfall (RF) & 1.4 & 1.1 & 1.5 & 1.1 & 1.7 & 1.2 & 1 & & 2 & 0.0453 \\
\hline Landuse/Land cover (LULC) & 1.2 & 1.4 & 1.7 & 1.2 & 1.5 & 1.6 & 1.4 & 1 & 1 & 0.0180 \\
\hline
\end{tabular}

Table 4 The quantity of themes (n), the greatest eigenvalue of pairwise comparison decision matrix ( $\lambda \max )$, consistency index $(\mathrm{CI})$, random consistency index (RI) and consistency ratio (CR) for the chosen themes to anticipate the GWPZs map in this investigation

\begin{tabular}{llrlll}
\hline Themes & $\mathrm{N}$ & $\lambda \max$ & $C I$ & $R I$ & $\mathrm{CR}$ \\
\hline Geology (GG) & 11 & 11.762 & 0.101 & 1.43 & 0.051 \\
Geomorphology (GM) & 5 & 5.089 & 0.013 & 0.70 & 0.030 \\
Soil Type (ST) & 10 & 10.933 & 0.107 & 1.45 & 0.072 \\
Slope (SL) & 5 & 5.173 & 0.018 & 1.12 & 0.030 \\
Lineament density (LD) & 5 & 5.320 & 0.033 & 1.12 & 0.021 \\
Drainage density (DD) & 5 & 5.649 & 0.080 & 1.12 & 0.048 \\
Rainfall (RF) & 5 & 5.581 & 0.039 & 1.12 & 0.029 \\
Landuse/Land cover (LULC) & 10 & 10.866 & 0.111 & 1.36 & 0.067 \\
\hline
\end{tabular}

where $L_{i}$ represents the length of the ith lineament, $\sum L_{i}$ represents the total length of the entire lineaments $(\mathrm{km})$, and A is the grid area $\left(\mathrm{km}^{2}\right)$.

The geomorphology and slope thematic maps were created using the Digital Elevation Model (DEM) of the Advanced Spaceborne Thermal Emission and Reflection Radiometer (ASTER) of 2019 with a $30 \mathrm{~m}$ spatial resolution. ASTER-DEM (https://search.earthdata.nasa.gov/ search) was adopted to prepare the drainage map, which was then processed to create the drainage density map. The study area's drainage density layer was made utilizing the line density tool and the stream network utilizing Eq. (2). The stream network was established from DEM by following the procedures in the hydrology toolbox for "fill DEM, flow direction, flow accumulation, stream order, and stream to feature."

$\operatorname{Dd}=\sum_{i=1}^{n} \frac{D_{i}}{A}$

where $\sum D_{i}$ represents the total length of the entire streams in stream order $\mathrm{i}(\mathrm{km})$ and A represents the watershed area $\left(\mathrm{km}^{2}\right)$. The resulting drainage density data were categorized in order to create a drainage density map of the research region. LULC map of the study was generated from a mosaicked Landsat ETM data of March 10, 2018 series via supervised classification of the chromaticity composite of the band 4, 3 and 2 to derive the land use classification in GIS software package.

Data from seven Nigerian Meteorological Agency (NIMET) stations in the survey area were used to calculate average yearly rainfall during a 10 -year period. To determine the spatial rainfall pattern of the research area, the data were 
Table 5 Allocated and normalized weights of the features of themes for the delineation of the groundwater potentials in the study area

\begin{tabular}{|c|c|c|c|c|c|c|}
\hline Influencing parameter & Sub-classes & Weight & Normalized weight & Rank & Area $\left(\mathrm{km}^{2}\right)$ & Area $(\%)$ \\
\hline \multirow[t]{5}{*}{ Geology } & Alluvium & 2 & 0.1204 & \multirow[t]{5}{*}{0.181} & 1.15 & 0.36 \\
\hline & Basalt & 1 & 0.1078 & & 2.21 & 0.10 \\
\hline & Sandstone & 3 & 0.3621 & & 17.23 & 3.84 \\
\hline & Shale & 2 & 0.1310 & & 7.09 & 2.01 \\
\hline & Migmatite & 1 & 0.1078 & & 358.95 & 90.14 \\
\hline \multirow[t]{4}{*}{ Geomorphology } & Lowland & 4 & 0.2011 & \multirow[t]{4}{*}{0.158} & 256.85 & 69.54 \\
\hline & Plains & 3 & 0.2008 & & 128.06 & 25.77 \\
\hline & Ridge & 2 & 0.1102 & & 11.1 & 3.13 \\
\hline & Hill & 1 & 0.1010 & & 6.0 & 1.56 \\
\hline \multirow[t]{3}{*}{ Soil type } & Lithosols & 3 & 0.1317 & \multirow[t]{3}{*}{0.123} & 196.80 & 53.06 \\
\hline & Ferruginous & 2 & 0.1205 & & 38.72 & 8.33 \\
\hline & Red Ferralsols & 1 & 0.1078 & & 166.52 & 38.64 \\
\hline \multirow[t]{4}{*}{ Slope (SL) } & $<8.12$ & 4 & 0.2316 & \multirow[t]{4}{*}{0.112} & 226.38 & 64.00 \\
\hline & $8.13-14$ & 3 & 0.1654 & & 172.31 & 34.87 \\
\hline & $14.01-19.88$ & 2 & 0.1253 & & 1.53 & 0.41 \\
\hline & $>19.88$ & 1 & 0.1212 & & 1.82 & 0.72 \\
\hline \multirow[t]{4}{*}{ Lineament density } & $0-1.07$ & 1 & 0.1243 & \multirow[t]{4}{*}{0.097} & 392.03 & 96.23 \\
\hline & $1.08-2.14$ & 2 & 0.1342 & & 7.23 & 3.11 \\
\hline & $2.15-3.2$ & 3 & 0.1629 & & 1.58 & 0.38 \\
\hline & $3.21-4.27$ & 4 & 0.1902 & & 1.18 & 0.28 \\
\hline \multirow[t]{4}{*}{ Drainage density } & $0-6.5$ & 4 & 0.2011 & \multirow[t]{4}{*}{0.069} & 383.48 & 93.62 \\
\hline & $6.51-13$ & 3 & 0.1874 & & 15.42 & 5.33 \\
\hline & $13.1-19.5$ & 2 & 0.1368 & & 1.32 & 0.33 \\
\hline & $19.6-26$ & 1 & 0.1100 & & 1.82 & 0.72 \\
\hline \multirow[t]{4}{*}{ Rainfall } & $1534.6-1572.2$ & 1 & 0.1221 & \multirow[t]{4}{*}{0.045} & 56.54 & 12.96 \\
\hline & $1572.4-1610.0$ & 2 & 0.1368 & & 245.91 & 60.59 \\
\hline & $1610.1-1647.7$ & 3 & 0.1927 & & 89.37 & 22.19 \\
\hline & $1647.8-1685.4$ & 4 & 0.2011 & & 10.22 & 4.26 \\
\hline \multirow[t]{4}{*}{ Landuse/Land cover } & Rock Exposure & 1 & 0.1018 & \multirow[t]{4}{*}{0.018} & 38.72 & 8.23 \\
\hline & Settlement & 2 & 0.1328 & & 180.52 & 43.11 \\
\hline & Vegetation & 3 & 0.1179 & & 135.52 & 38.38 \\
\hline & Water body & 4 & 0.1093 & & 50.14 & 10.28 \\
\hline
\end{tabular}

analyzed using the Thiessen polygon approach in the ArcGIS 10.5 software package.

Following the preparation of all the various thematic maps with distinct features (such as rainfall, slope, drainage density, soil, land use, slope, geology, and lineament thematic maps), the maps were transformed to raster format and appropriate weights were given in sequence of their hierarchy in groundwater potentiality adopting the analytic hierarchy process (AHP).

\section{Multi-criteria decision assessment utilizing AHP}

AHP is a decision assistance tool created by Saaty (1990) that is commonly utilized in reaching complex decisions primarily on the pairwise comparison. The first stage of the AHP technique begins with the selection of essential criteria for the target decision and the creation of a pairwise comparison matrix based on expert judgments or decision between the criteria (Saaty 1990, 2005). The complicated decision-making procedure between the criteria is simplified to a single level with this pairwise comparison matrix (Eq. 3), and the comparative relevance values of the criteria are derived. The criteria are compared using Saaty's 1-9 significance scale (Table 1).

$$
\mathrm{A}=\begin{array}{lllll}
a_{21} & a_{22} & a_{23} & a_{\ldots} & a_{2 n} \\
a_{31} & a_{32} & a_{33} & a_{\ldots} & a_{3 n} \\
a_{\ldots} & a_{\ldots} & a_{\ldots} & a_{\ldots} & a_{\ldots n} \\
a_{n 1} & a_{\ldots} & a_{\ldots} & a_{\ldots} & a_{n n}
\end{array}
$$

where $a_{n n}$ is the judgment matrix element and $a$ represents the nth indicator unit.

The second stage of the AHP computations as indicated in Eq. (4) is to calculate the normalized weights utilizing the criteria' geometric mean. 


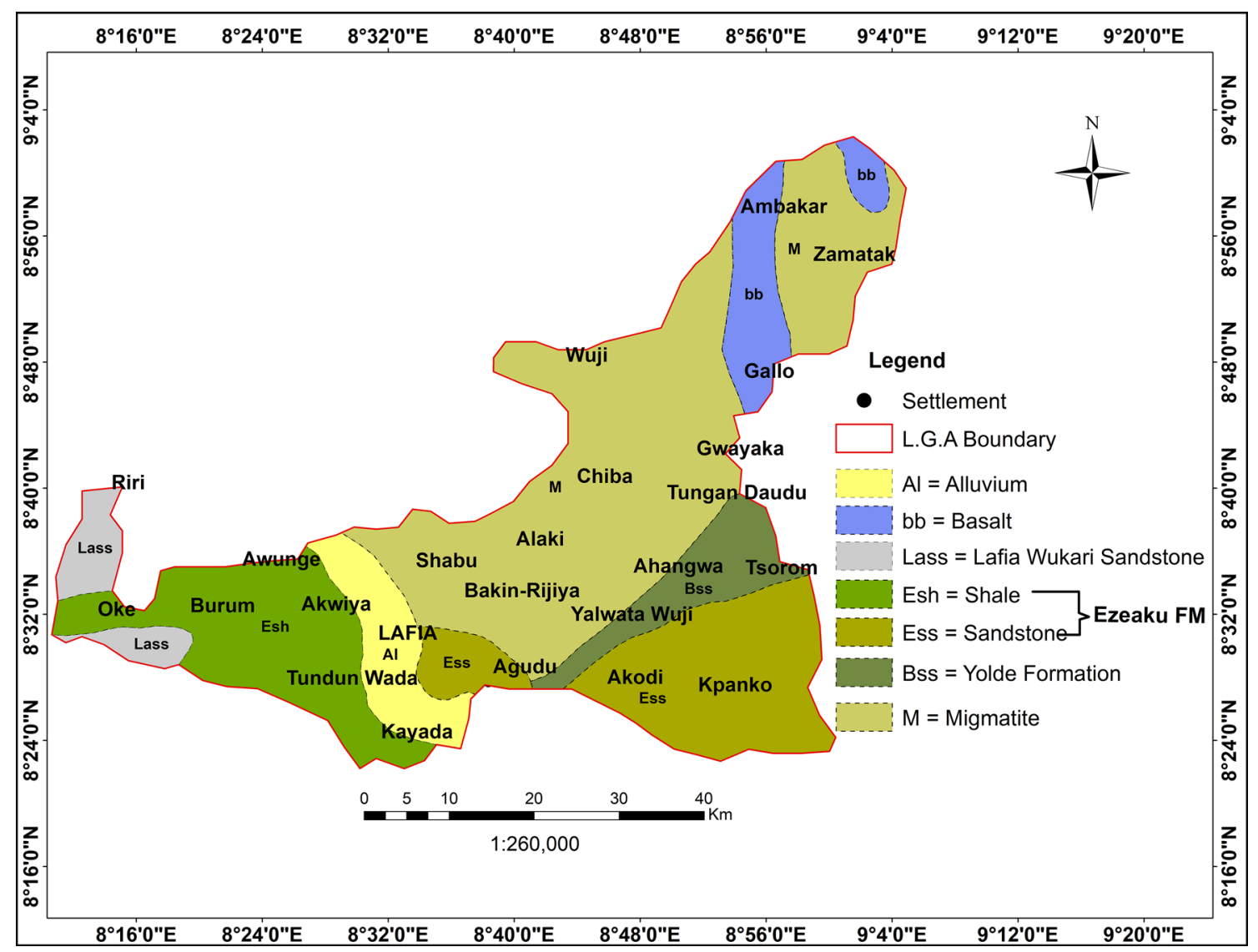

Fig. 4 Geologic map of the study area

$$
\mathrm{Wn}=\frac{G m}{\sum_{i-1}^{n} G m}
$$

where W donates the Eigen vector and Gm donates the geometric mean of the ith row of the judgment.

The final stage of the AHP approach is to examine the consistency of the normalized criteria weights. Equation (5) shown below is used to determine the consistency ratio (CR). The CR value has to be lower than 0.10 for the weights to be deemed consistent. The pairwise comparisons must be re-examined if the CR value is more than 0.10 .

$\mathrm{CR}=\frac{C I}{R I}$

where CR stands for consistency ratio, CI stands for consistency index determined with Eq. (6), and RI stands for random consistency index (Table 2 adopted from Saaty 1990).

$\mathrm{CI}=\frac{\lambda \max -n}{n-1}$

where $\lambda \max$ donates the maximum eigenvalue of the judgment matrix, obtained using Eq. (7). $\lambda \max =\frac{1}{n} \sum_{i-1}^{n} \frac{\left(A_{w}\right) i}{w_{i}}$

Table 3 demonstrates the pairwise comparison matrix, allocated weight and normalized weight values of the criteria and sub-criteria utilized in present study.

The consistency ratios (CR) of the pairwise comparisons are less than 0.1 , and the $\mathrm{CR}$ values of the criterion, along with the values of $\lambda \max , \mathrm{CI}$, and RI, are revealed in Table 4.

Criteria standardization, demarcation and validation of groundwater potential zones (GWPZs) map.

Data standardization, in conjunction with AHP, is extensively utilized in GIS-based decision support research, as it simplifies all decision criteria to a single scale of measurement (Aykut 2021; Benjmel et al. 2020; Panahi et al. 2017). To standardize each raster GIS-based criteria map, rating values scale of 1-4 (very poor, poor, moderate, and good) were allocated (Table 5). The weighted overlay approach was used to generate the groundwater potential zones (GWPZs) for Lafia district after assigning score and weight values to every criterion and ensuring that they were consistent. The GWPZ Eq. (8) is illustrated below: 


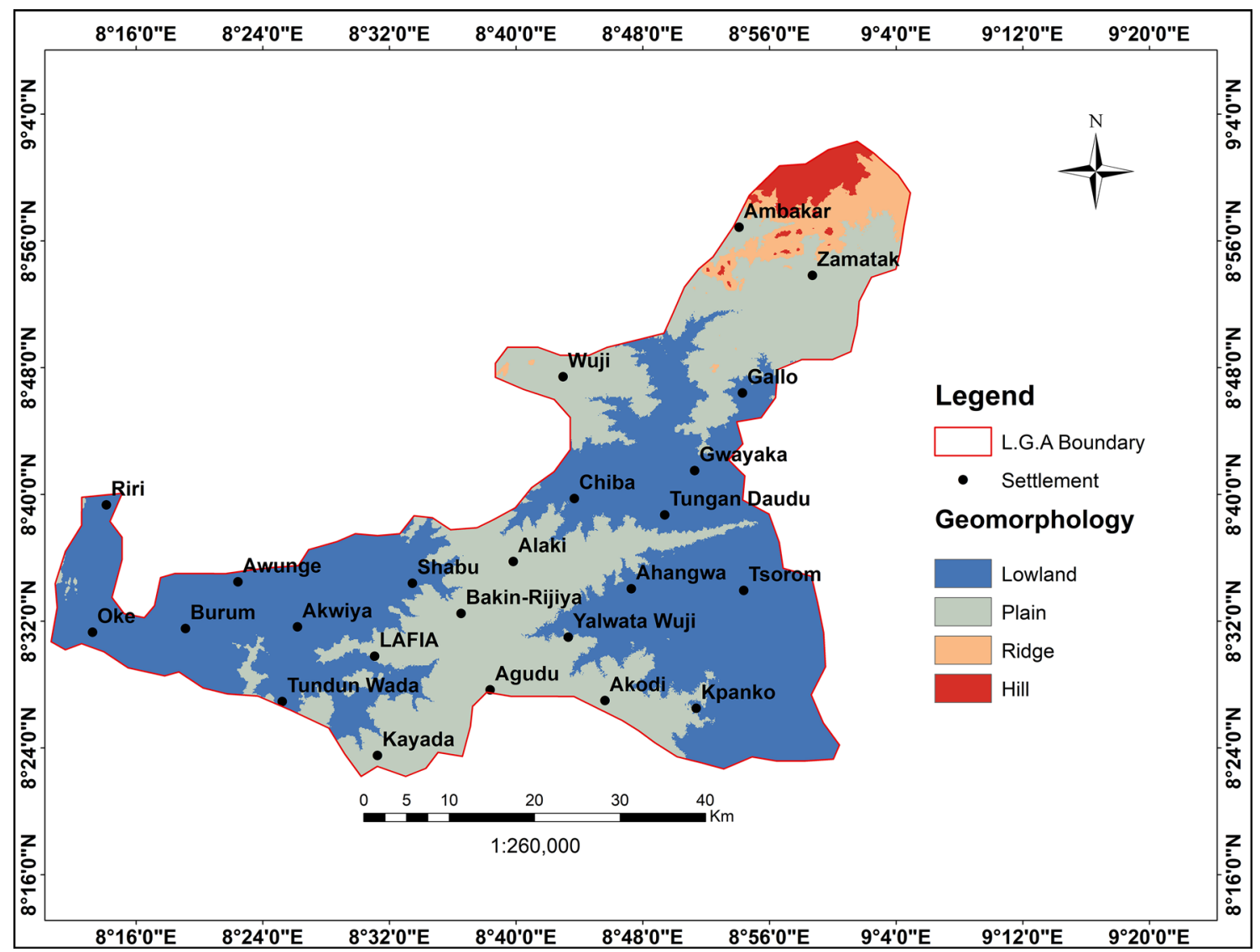

Fig. 5 Geomorphology map of the study area

$$
\mathrm{GWPZ}=\sum_{i=1}^{n} w_{i} x r_{i}
$$

where $n$ denotes the number of criteria, $w_{i}$ denotes the relative weight of criterion $i$ and $r_{i}$ denotes the criterion's standardized score.

Existing wells and boreholes data were ultimately collected in the research region. For verification of the indicated potential groundwater map, the wells and boreholes data were used as a recommended guide for a quick assessment of the groundwater occurrence at local scale in the research region.

\section{Results and discussion}

\section{Geology}

Geology completely determines the penetration and percolation of groundwater. As a result, it is a crucial criterion for assessing groundwater potential (Aju et al. 2021). The high permeability and porosity of the geologic units boost groundwater storage and yields (Yıldırım 2021).

The geology is the 8th essential parameters, with normalized weight of 0.181 adopted to ascertain GWPZs of Lafia district. The corresponding weight values of these geologic formations were stratigraphically arranged as alluvium, basalt, sandstone, shale and migmatite (Table 5). The weighted value of " 3 " was assigned to sandstone, indicating that it has a good potential for groundwater, while weighted value of " 2 " was given to alluvium and shale, suggesting that they have moderate potentials for groundwater and basalt and migmatite were weighted with "1" signifying poor and very poor potentials for groundwater. The research area is covered with $60 \%$ Basement complex rocks, while the remaining 40 percent consists of Cretaceous-Tertiary Middle Benue Trough's sedimentary rocks (Fig. 4). The basement complex rocks in the study area are migmatite-gneiss complex and the basaltic rocks. The prevalent and most vast rock in the northern portion of the study area is the migmatite complex which is Neo-Proterozoic to Meso-Archean in age covering approximately $358.95 \mathrm{~km}^{2}$ (69.54\%). The basaltic counterpart of the basement complex is Pan-African in age covers $2.21 \mathrm{~km}^{2}$ (0.10 percent). The southern region of 


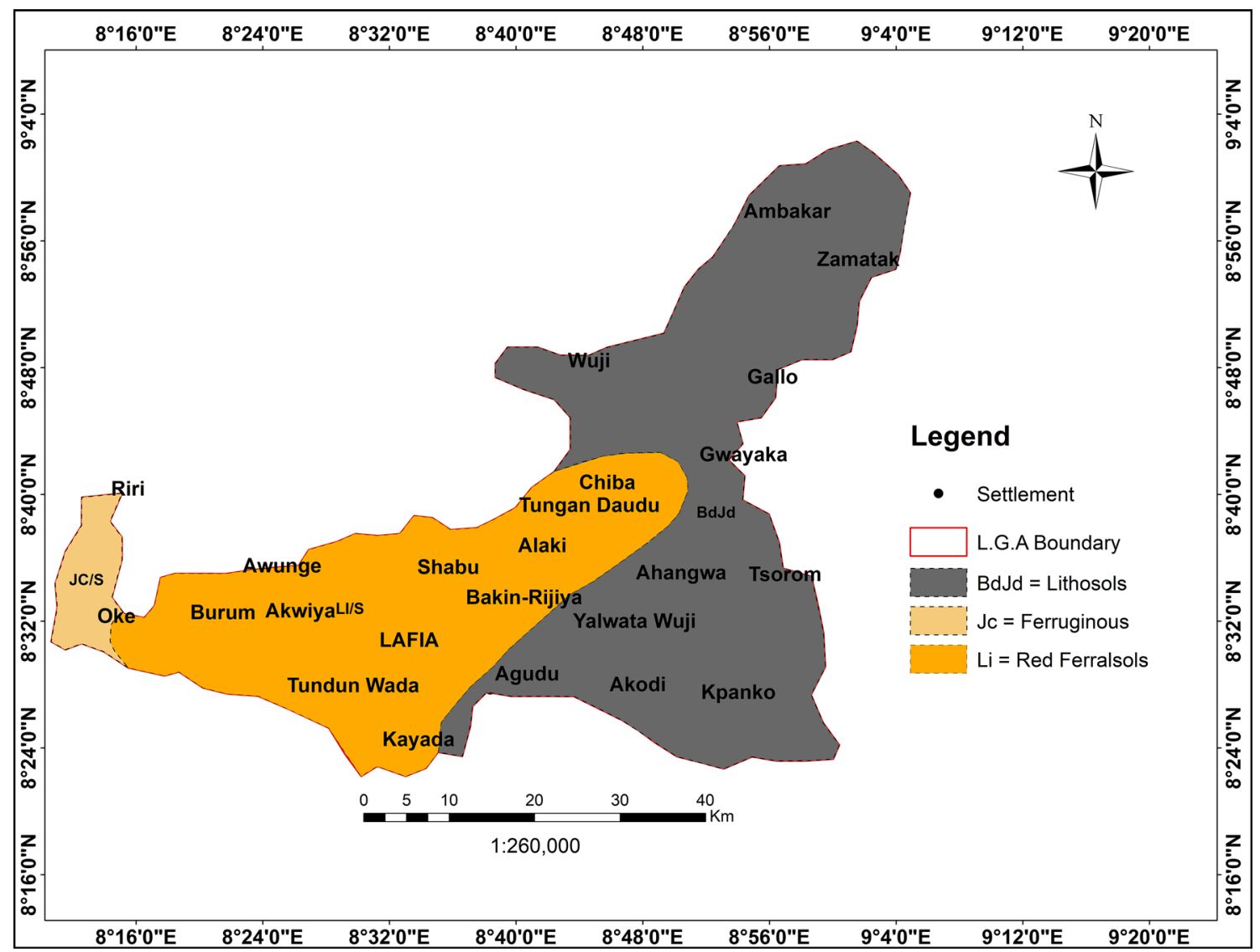

Fig. 6 Soil map of the study area

the area forms section of the Middle Benue Trough which is underlain by Cretaceous-Tertiary sedimentary rocks, namely Yolde Formation, Ezeaku Formation, Lafia Wukari Sandstone and Alluvium deposit in sequence order. Yolde Formation is made up of feldspathic sandstone, calcareous sandstone and shelly limestone extending $7.09 \mathrm{~km}^{2}$ (2.01\%). Eze-aku Formation contains majorly calcareous shales, micaceous fine to medium friable sandstones and beds of limestones which in some areas are shelly covers a total areal of $17.23 \mathrm{~km}^{2}(3.84 \%)$ and $12.39 \mathrm{~km}^{2}(2.38 \%)$, respectively. Lafia Wukari Sandstone comprises of cross-bedded, fine-coarse grained sandstones, sometimes conglomerates, thick bands of shales and claystone toward the top are highly porous and permeable as well as the most prolific aquifer in the Middle Benue Trough extending $3.02 \mathrm{~km}^{2}(1.17 \%)$, whereas the Alluvium consists mainly of sandstones and mudstones of almost $1.15 \mathrm{~km}^{2}$ ( 0.36 percent).

\section{Geomorphology}

Geomorphology is the 7th influential parameters, with normalize weight of 0.158 employed to define GWPZs of
Lafia district (Table 3). Lowlands, plains, ridges, and hills are the four geomorphological types that make up the study area (Fig. 5). These categories encompass $256.85 \mathrm{~km}^{2}$ (69.54\%), $128.06 \mathrm{~km}^{2}(25.77 \%), 11.1 \mathrm{~km}^{2}(3.13 \%)$ and 6.0 $\mathrm{km}^{2}(1.56 \%)$ of the Lafia district. The "lowlands" category has the highest normalized weighting value of 0.2011 and assigned weight of 4 based on infiltration attributes and storage capacity, whereas the "hills" category has the lowest normalized weighting value of 0.1010 and assigned weight of $=1$ (Table 5). The lowlands and plains are located in the north-eastern and southern segment of the study region, symbolizing the middle and lower flow of the drainage systems, while the ridges and hills are located in the northern part of the study area, covering the catchment regions.

\section{Soil type}

The increase in water entry into the soil is affected by soil type, which is determined by the activities of pore saturation or desaturation (Gbosh et al. 2020). Water transport into the ground is controlled by the porosity of the soil categories. Soil type with coarse-grained matrix (e.g., lithosols) has 


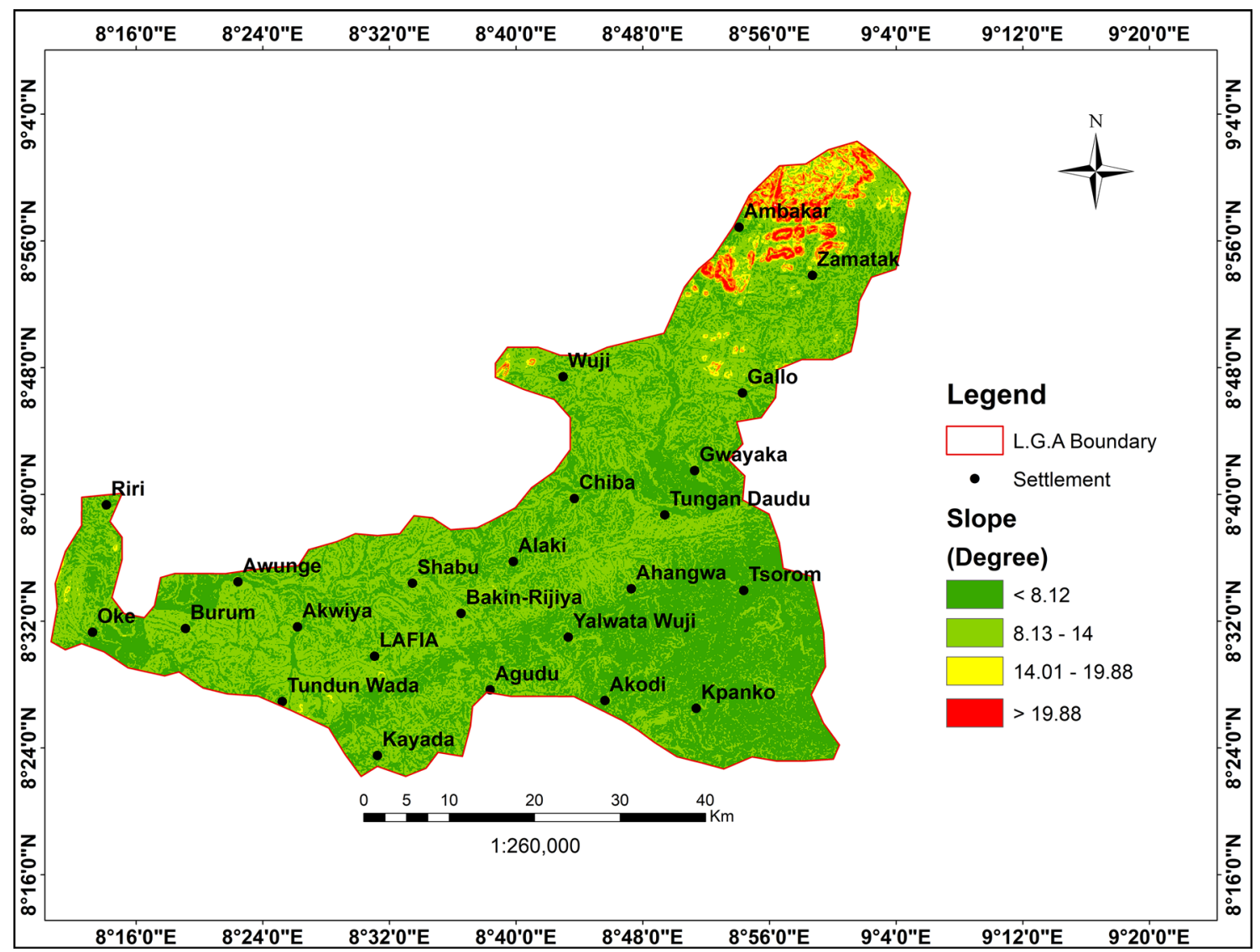

Fig. 7 Slope map of the study area

good groundwater potential, whereas soil type with finegrained matrix (ferralsols) has poor groundwater potential (Ifediegwu et al. 2019).

In the study, soil type is the 6th among the most significant parameters utilized to identify groundwater potential zones based on normalized weighting (Table 3 ). The study area contains three soil categories. These are lithosols, ferruginous and red ferralsols (Fig. 6). These soil type categories were assigned weights and ranked based on permeability, which differed based on particle sizes. The assigned weight values of soil type categories in decreasing order were established as lithosols (3), ferruginous (2) and red ferralsols (1) (Table 5). Whereas the lithosols has the highest normalized weight value 0.1317 , the normalized weight of ferruginous is 0.1205 and the normalized weight value of red ferralsols is 0.1078; the surrounded area and percentage of these soil categories is $196.80 \mathrm{~km}^{2}(56.06 \%), 38,72 \mathrm{~km}^{2}$ $(8.33 \%)$ and $166.52 \mathrm{~km} 2(38.64 \%)$, respectively.

\section{Slope}

Because the slope has a direct influence on the surface runoff mechanism, it is critical for groundwater recharge (Zghibi et al. 2020). Preliminary investigations have revealed that the low slope regions have a good potential for groundwater storage due to the extended residence time for rainwater to infiltrate the subsurface. Steep slope regions, on the other hand, possess poor groundwater potential due to rapid water runoff from the landscape (Igwe et al. 2020).

Slope is ranked 5th with normalized weight of 0.1121 based on relative influence on groundwater potential zones identification among parameters chosen in this study (Table 3). With rising normalized weight and assigned weight values, the slope of Lafia district was split into four classes: $<8.12^{\circ}$ (good potential), $8.13-14^{\circ}$ (moderate potential), $14.01-19.88^{\circ}$ (poor potential), $>19.88^{\circ}$ (very poor potential), and more than 40 (very low potential) (Fig. 7). The assigned weight of individual theme layers with values between "1" to "4" represent $64.0 \%\left(226.38 \mathrm{~km}^{2}\right), 34.87 \%$ $\left(172.31 \mathrm{~km}^{2}\right), 0.41 \%\left(1.53 \mathrm{~km}^{2}\right), 0.72 \%\left(1.82 \mathrm{~km}^{2}\right)$ of the study area.

\section{Lineament density}

Lineament features are the criteria that ultimately determines permeability. Water circulation is greater in regions 


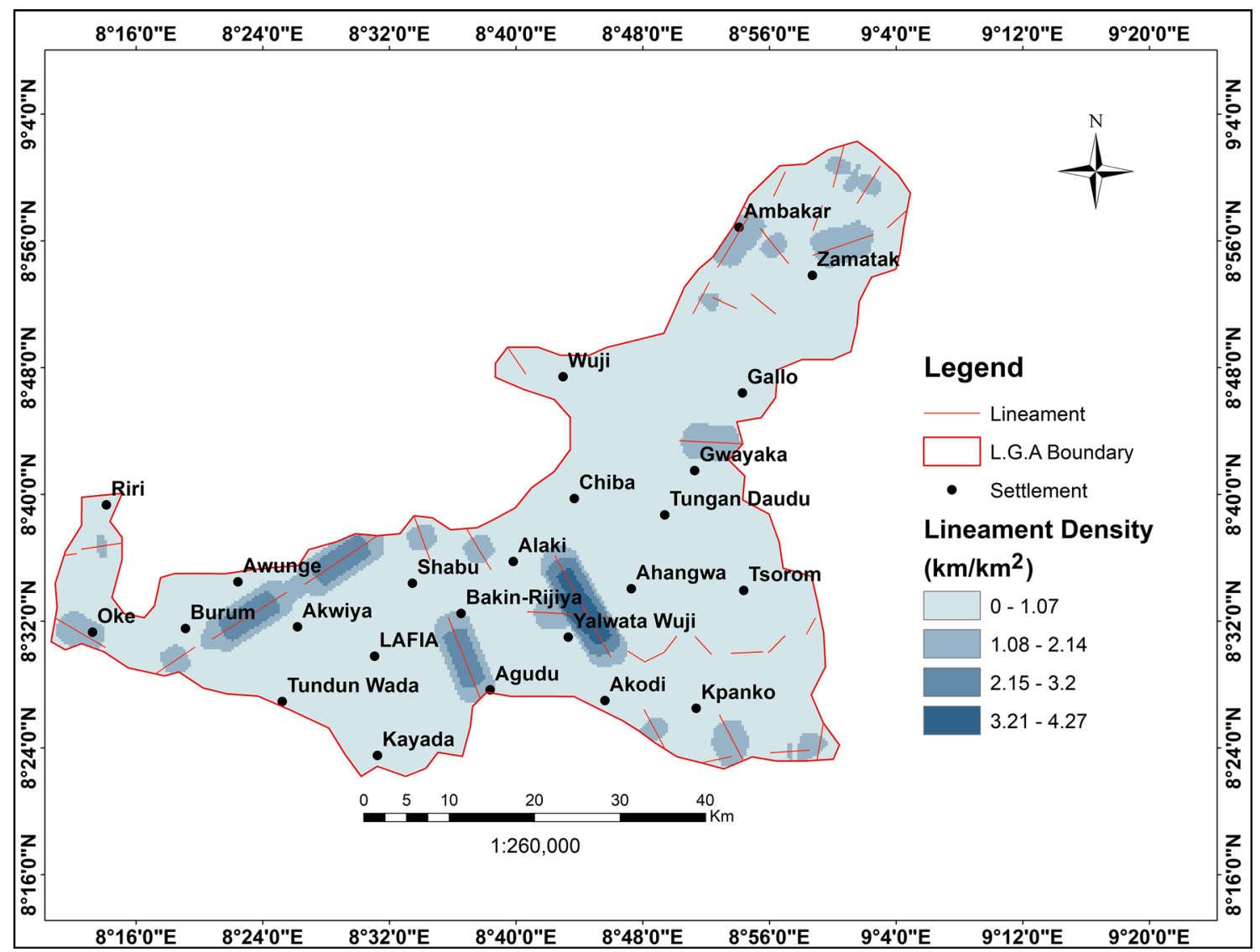

Fig. 8 Lineament density map of the study area

with high lineament density; therefore, groundwater potential is as well greater in these regions (Lentswe and Molwalefhe 2020).

Lineament density is ranked 4th in normalized weighting value of 0.0970 among parameters utilized to establish groundwater potentials zones in current study (Table 3). The principal lineaments in the Lafia district, particularly faults, trended between NW-SE and NE-SW (Fig. 8). In the study area, the lineament density ranged from 0 to $4.27 \mathrm{~km} / \mathrm{km}^{2}$, and the lineament density was divided into four categories. The regions of $96.23 \%\left(392.03 \mathrm{~km}^{2}\right), 3.11 \%\left(7.23 \mathrm{~km}^{2}\right)$, $0.38 \%\left(1.58 \mathrm{~km}^{2}\right)$, and $0.28 \%\left(1.18 \mathrm{~km}^{2}\right)$, respectively, are occupied by assigned weight of " 1 " to "4" (Table 4).

\section{Drainage density}

The rate of water flow and penetration into the aquifer are influenced by drainage density (Thapa et al. 2017). Low drainage density is caused by high permeability of underlying rocks (Shao et al. 2020). Thus, zones with low drainage density exhibit good groundwater potential (Gnanachandrasamy et al. 2018).
In this study, drainage density values range from 0 to $1.38 \mathrm{~km} / \mathrm{km} 2$. Among parameters chosen in this study, drainage density ranks $3^{\text {rd }}$ with normalized weight of 0.089 based on relative importance in assessing groundwater potential zones (Table 3). The drainage density map of the area was classified into four categories (Fig. 9). The assigned weight of the individual themes ranges from 1 to 4 with increasing normalized weighting values (Table 5). The high potential ranking theme layer of 4 covers $93.62 \%\left(383.48 \mathrm{~km}^{2}\right)$ of the area, whereas the ranking theme layers " 3, " "2," and "1," respectively, cover $5.33 \%\left(15.42 \mathrm{~km}^{2}\right), 0.33 \%\left(1.32 \mathrm{~km}^{2}\right)$, and $0.72 \%\left(1.82 \mathrm{~km}^{2}\right)$ of the study area.

\section{Rainfall}

Rainfall is the 2nd most important factor, with a normalized weighting value of 0.0453 among variables considered in this study to establish GWPZs (Table 3). The average annual precipitation of the area ranges from 1534.6 to $1685.4 \mathrm{~mm}$, and it is divided into four separate classes (Table 5). These theme layers' weights range from "1" to "4," with normalized weighting increasing in lockstep with the allotted weights. In the southern sections of the area, yearly average 


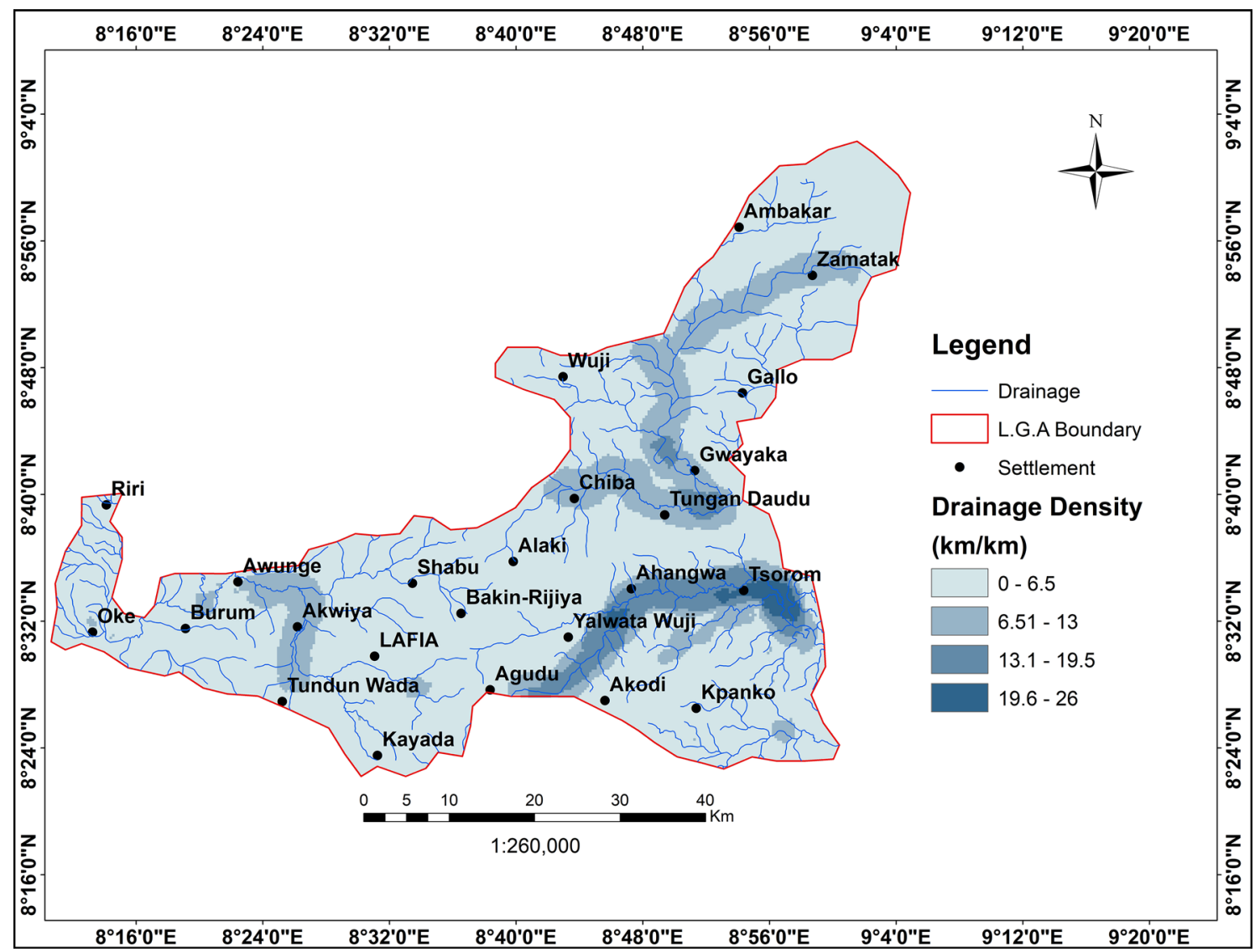

Fig. 9 Drainage density map of the study area

rainfall amounts are higher, but in the northern regions of the area, average yearly precipitation amounts are lower (Fig. 10). Ultimately, the area in general experiences nearly distinct rainfall patterns. It is excellent to said that not only the quantity of rainfall in the area is important, but also the period and intensity of rainfall as well plays a key function in recharging the groundwater. Small amounts of low intensity rainfall will make a good impact to the groundwater over a prolonged period of time (Nasir et al. 2018).

\section{Land use/land cover (LULC)}

Land use/land cover pattern is among the most important elements regulating surface runoff due to evapotranspiration, penetration and condensation are all dependent on factors like vegetation type and soil wetness. As a result, it has a significant impact on groundwater recharge.

Land use/land cover map have a normalized weight of 0.045 , which ranks 1 st among the parameters evaluated by this investigation to determine GWPZs (Table 3). The land-use types were categorized in ascending order of normalized weight: bare land, settlement, vegetation and water body areas (Table 5). Based on assigned weighting value, the land-use classes were ranked as follows: "1" for bare land (very poor potential), "2" for settlement (poor potential), "3" for vegetation (moderate potential), and "4" for waterbody (good potential) (Fig. 11). These ranking categories encompass $8.23 \%\left(38.72 \mathrm{~km}^{2}\right), 43.11 \%\left(180.52 \mathrm{~km}^{2}\right), 38.38 \%$ $\left(135.52 \mathrm{~km}^{2}\right)$, and $10.28 \%\left(50.14 \mathrm{~km}^{2}\right)$ of the research area. In the weighting and ranking of LULC types, amount of recharge, evapotranspiration and runoff, which assist provide the penetration rate in categories, were taken into account.

\section{Determining the possible groundwater zone}

Groundwater occurrence and movement controlling criteria were unified in ArcGIS to ascertain the groundwater potential zones of Lafia district, utilizing the weightages derived by the AHP approach. The resultant map was divided into four categories: very poor potential, poor potential, moderate 


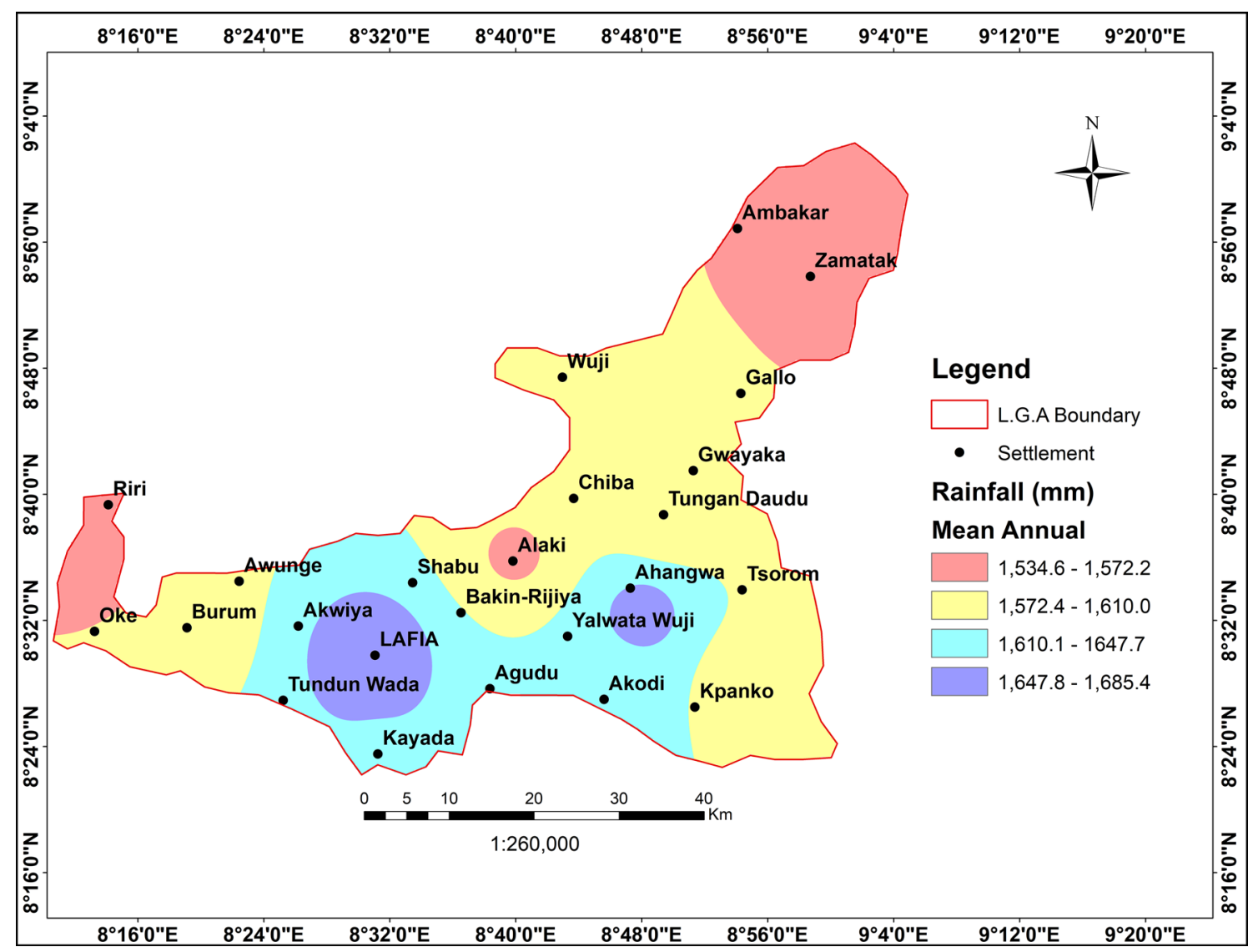

Fig. 10 Rainfall distribution map of the study area

potential, and good potential (Fig. 12). Very poor potential zones account for roughly $10.0 \%$ of the entire area (28.64 $\mathrm{km}^{2}$ ), whereas the poor potential zones represent about $57.8 \%$ of the total area of the study $\left(218.6 \mathrm{~km}^{2}\right)$. Around $12.9 \%$ of the total area $\left(56.5 \mathrm{~km}^{2}\right)$ is rated as having moderate potential zones, while $19.3 \%\left(98.3 \mathrm{~km}^{2}\right)$ is classified as having good potential zones (Table 6).

The extreme down-stream part of the Lafia district with slope less than 8.12 degrees, and the Lafia Wakiri Sandstone and Ezeaku Formations represent good and moderate potential zones. Conversely, poor and very poor potential zones in the crystalline aquifer districts are generally associated with secondary porosity, such as high lineament density (3.21-4.27 km/ $\mathrm{km}^{2}$ ). The crystalline rocks (migmatite and basalt), denudational-structural hills in the upstream portion fall into poor and very poor potential zones.

\section{Precision evaluation of possible groundwater zones}

Data on current boreholes and wells were collected for 50 boreholes and wells in the study area in attempt to certify the identification of the regions of potential groundwater as indicated in the AHP, RS and GIS based groundwater potential map (Table 7).

All through the study area, the depth of the borehole differs from 9.6 to $85.7 \mathrm{~m}$, which is really a complicated and irregular representation of the aquiferous zones in a basement and sedimentary environments. The saturated thickness also fluctuates between of $35.9 \mathrm{~m}$ in sandstone to $13.5 \mathrm{~m}$ in alluvium deposit and $12.6 \mathrm{~m}$ in migmatite region as well as from $11.2 \mathrm{~m}$ in shale environments to 9.5 in basaltic rock area. Boreholes yields range from 28.8 to $83.6 \mathrm{~m}^{3} /$ day (av. $52.1 \mathrm{~m}^{3} /$ day) in sandstone environments, yields value in 


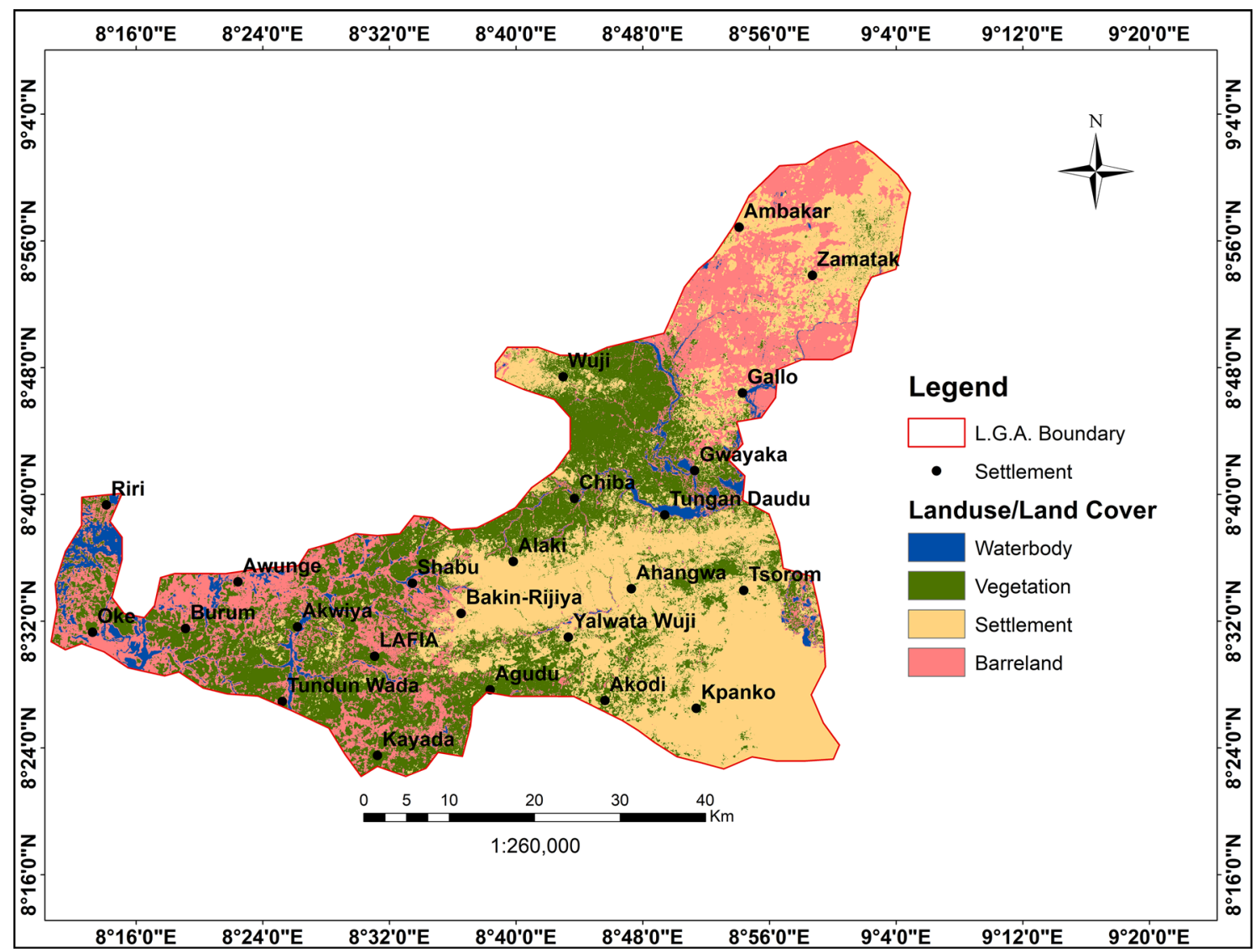

Fig. 11 Land use/land cover map of the study area

alluvium deposit varied from 23.2 to $46.9 \mathrm{~m}^{3} /$ day (av. 34.5 $\mathrm{m}^{3} /$ day), while in shale units yields changed from 8.7 to $14.6 \mathrm{~m}^{3} /$ day (av. $10.2 \mathrm{~m}^{3} /$ day) whereas in basaltic rock settings yields differ from 5.6 to $10.4 \mathrm{~m}^{3} /$ day (av. $12.3 \mathrm{~m}^{3} /$ day) relative to 10.5 to $18.3 \mathrm{~m}^{3} /$ day (av. $21 \mathrm{~m}^{3} /$ day) in migmatite terrain (Fig. 13). Borehole data were overlaid on the potential groundwater map, and numbers of wells were examined for various groundwater potential zones with specific yield ranges. Eventually, high-yielding wells are mainly in sandstone, alluvium and shale environments associated with good and moderate groundwater potential areas. Zones of low-yield boreholes are typically in areas underlain by migmatite and basaltic rocks. These also showed a good correlation with the GIS-based groundwater potential areas.

\section{Conclusion}

The groundwater potential for the Lafia district was investigated in the present study utilizing an integrated GIS and AHP technique. The AHP approach was chosen for the multi-criteria decision making between the criteria influencing the occurrence and movement of groundwater in the area. The thematic maps of geology, land use/land cover, lineament density, slope, drainage density, soil type, rainfall and geomorphology layers were selected, assessed and discussed. These themes were weighted either within and between individuals by making pairwise comparisons and were aggregated in the GIS utilizing the weighted overlay 


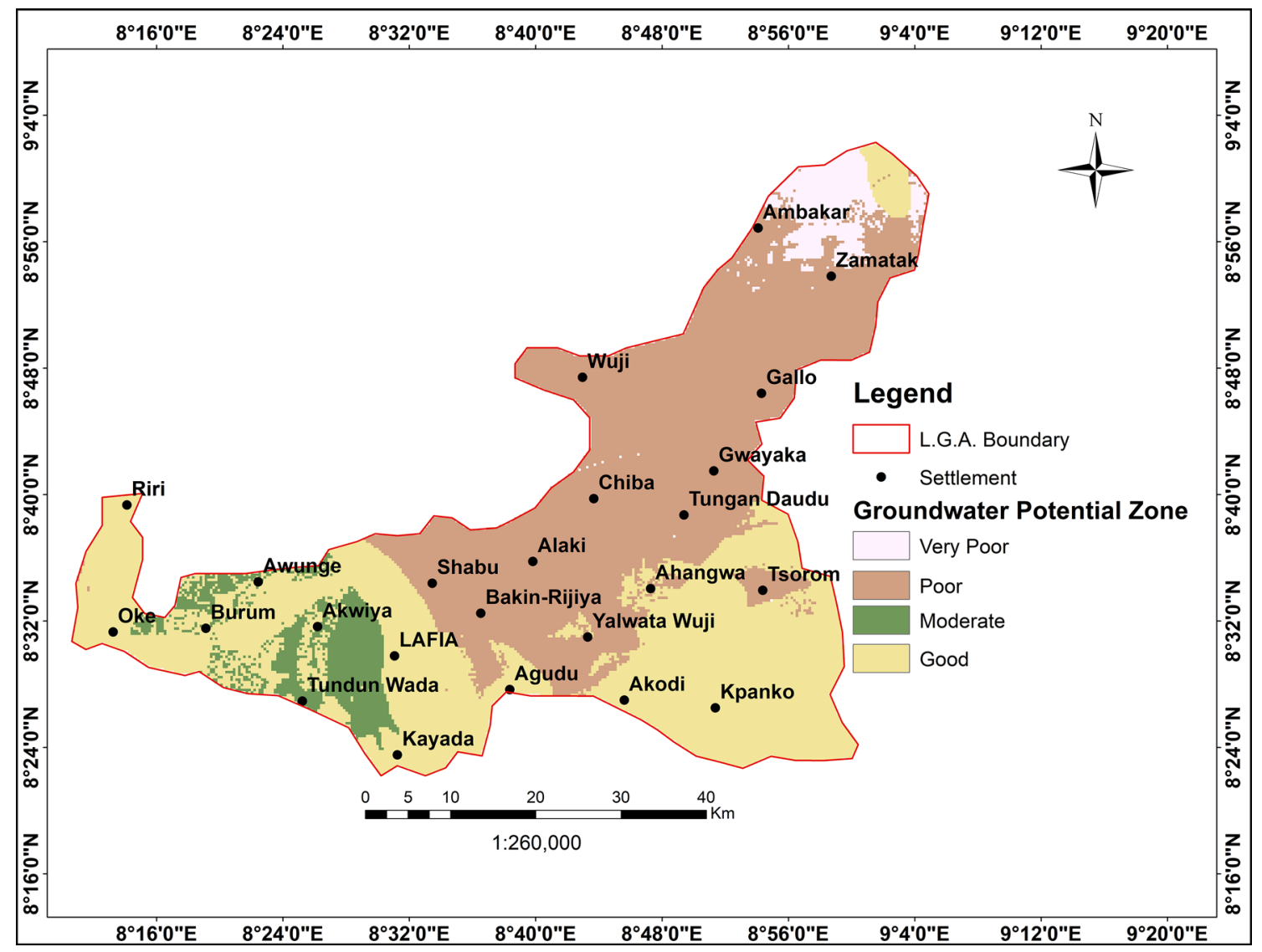

Fig. 12 Potential groundwater zones map of the study area

Table 6 Identification of potential groundwater zones and distribution areas next to the corresponding yield categories

\begin{tabular}{llcl}
\hline Potential zones & Area $(\%)$ & Area $\left(\mathrm{km}^{2}\right)$ & Classification by yield \\
\hline Very bad & 10.0 & 28.64 & $<10.4 \mathrm{~m}^{3} /$ day \\
Bad & 57.8 & 218.6 & $10.5-18.3 \mathrm{~m}^{3} /$ day \\
Fair & 12.9 & 56.5 & $14.6-46.9 \mathrm{~m}^{3} /$ day \\
Nice & 19.3 & 98.3 & $>50.0 \mathrm{~m}^{3} /$ day \\
\hline
\end{tabular}

approach. As a result, the groundwater potential zones map of the research area was made.

The map of groundwater potential zones was divided into four categories: good potential, moderate potential, poor potential, and very poor potential. The good potential regions of groundwater cover approximately $98.3 \mathrm{~km}^{2}$ accounting for $19.3 \%$ of the overall area, moderate potential encompasses roughly $56.5 \mathrm{~km}^{2}$ representing $12.9 \%$ whereas poor potential represent $57.8 \%\left(218.6 \mathrm{~km}^{2}\right)$ and very poor surrounded about $28.64 \mathrm{~km}^{2}$ representing $10 \%$ of the entire district. Lastly, the integrity of the resulting groundwater potential zones map was validated by comparing it to the wells/boreholes yield spread throughout the study region. The average yield of the wells/boreholes is $>50.0 \mathrm{~m}^{3} /$ day for good potential zones; $14.6-46.9 \mathrm{~m}^{3} /$ day for moderate potential zones; $10.5-18.3 \mathrm{~m}^{3} /$ day for the poor potential zones; and $<10.4 \mathrm{~m}^{3} /$ day for very poor potential zones, respectively. The GWPZs map generated by the GIS integrated AHP approach is quite reliable, according to these results.

Because industries are few in this area, hence, residents rely on agriculture and livestock farming for a living. Agriculture occupies roughly $57.01 \%$ of the study area. Given these circumstances, the groundwater potential zones map demarcated result of present investigation will assist policymakers and relevant agencies with a forecast in groundwater management for agricultural and domestic uses. Furthermore, the methods applied in this research will aid other scholars conducting similar research around the globe. 


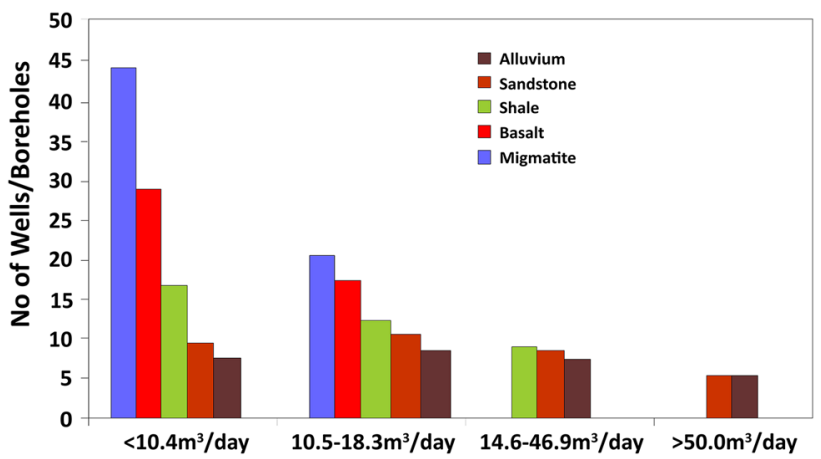

Fig. 13 Borehole yields in lithological types of the study area

Acknowledgements The author wishes to thank the department of the United States Geology Survey (USGS) by providing data for the analysis as well as other writers whose articles have made no small contribution.

Funding The author received no specific funding for this work.

\section{Declarations}

Conflict of interest No conflict of interest in this research.

Open Access This article is licensed under a Creative Commons Attribution 4.0 International License, which permits use, sharing, adaptation, distribution and reproduction in any medium or format, as long as you give appropriate credit to the original author(s) and the source, provide a link to the Creative Commons licence, and indicate if changes were made. The images or other third party material in this article are included in the article's Creative Commons licence, unless indicated otherwise in a credit line to the material. If material is not included in the article's Creative Commons licence and your intended use is not permitted by statutory regulation or exceeds the permitted use, you will need to obtain permission directly from the copyright holder. To view a copy of this licence, visit http://creativecommons.org/licenses/by/4.0/.

\section{References}

Achu AL, Reghunath R, Thomas J (2019) Mapping of groundwater recharge potential zones and identification of suitable site-specific recharge mechanisms in a tropical river basin. Earth Syst Environ. https://doi.org/10.1007/s41748-019-00138-5

Ahmad I, Dar MA, Andualem TG, Teka AH (2020) GIS-based multicriteria evaluation of groundwater potential of the Beshilo River basin Ethiopia. J Afr Earth Sci 164:103747

Aju CD, Achu AL, Raicy MC, Reghunath R (2021) Identification of suitable sites and structures for artificial groundwater recharge for sustainable water resources management in Vamanapuram River Basin, South India. HydroResearch 4:24-37

Aliabad FA, Shojaei S, Zare M, Ekhtesasi MR (2018) Assessment of the fuzzy ARTMAP neural network method performance in geological mapping using satellite images and Boolean logic. Int J Environ Sci Technol. https://doi.org/10.1007/s13762-018-1795-7

Allafta H, Opp C, Patra S (2021) Identification of groundwater potential zones using remote sensing and gis techniques: a case study of the Shatt Al-Arab Basin. Remote Sens 13:112. https://doi.org/ $10.3390 /$ rs 13010112 
Aykut T (2021) Determination of groundwater potential zones using geographical information systems (GIS) and analytic hierarchy process (AHP) between Edirne-Kalkansogut (northwestern Turkey). Groundw Sustain Dev 12:100545

Barhanu KG, Hatiye SD (2020) Identification of groundwater potential zones using proxy data: case study of Megech watershed Ethiopia. J Hydrol Reg Stud 28:100676

Benjmel K, Amraoui F, Boutaleb S, Ouchchen M, Tahiri A, Touab A (2020) Mapping of groundwater potential zones in crystalline terrain using remote sensing, GIS techniques, and multicriteria data analysis (case of the Ighrem region, Western Anti-Atlas, morocco). Wat 12:471

Das B, Pal S, Malik S, Chakrabortty R (2018) Modeling groundwater potential zones of Puruliya district, West Bengal, India using remote sensing and GIS techniques. Geol Ecol Landsc 3:223-237

Gebru H, Gebreyohannes T, Hagos E (2020) Identification of groundwater potential zones using analytical hierarchy process (AHP) and GIS-remote sensing integration, the case of Golina River Basin, Northern Ethiopia. Int J Adv Rem Sen GIS 9(1):3289-3311

Ghosh D, Mandal M, Karmakar M, Banerjee M, Mandal D (2020) Application of geospatial technology for delineating groundwater potential zones in the Gandheswari watershed West Bengal. Sustain Water Res Manage 6:14. https://doi.org/10.1007/ s40899-020-00372-0

Gnanachandrasamy G, Zhou Y, Bagyaraj M, Venkatramanan S, Ramkumar T, Wang S (2018) Remote sensing and GIS based groundwater potential zones mapping in Ariyalur district, Tamil Nadu. J Geol Soc India 92:484-490. https://doi.org/10.1007/ s12594-018-1046-Z

Guru B, Seshan K, Bera S (2017) Frequency ratio model for groundwater potential mapping and its sustainable management in cold desert, India. J King Saud Univ Sci 29:333-347. https://doi.org/ 10.1016/j.jksus.2016.08.003

Gyeltshen S, Tran TV, Gunda GKT, Kannaujiya S, Chatterjee RS, Champatiray PK (2020) Groundwater potential zones using a combination of geospatial technology and geophysical approach: case study in Dehradun, India. Hydrol Sci J 65:169-182

Hamdani N, Baali A (2020) Characterization of groundwater potential zones using analytic hierarchy process and integrated geomatic techniques in Central Middle Atlas (Morocco). Appl Geomat 12:323-335

Ifediegwu SI, Nnebedum DO, Nwatarali AN (2019) Identification of groundwater potential zones in the hard and soft rock terrains of Kogi State, North Central Nigeria: an integrated GIS and remote sensing techniques. SN Appl Sci 1:1151. https://doi.org/10.1007/ s42452-019-1181-1

Igwe O, Ifediegwu SI, Onwuka OS (2020) Determining the occurrence of potential groundwater zones using integrated hydrogeomorphic parameters, GIS and remote sensing in Enugu State, Southeastern. Nigeria Sust Wat Resour Manag 6:39. https://doi. org/10.1007/s40899-020-00397-5

Iloeje NP (1981) A new geography of Nigeria, new, revised. Longman Publishers, London

Kanagaraj G, Suganthi S, Elango L, Magesh NS (2019) Assessment of groundwater potential zones in Vellore district, Tamil Nadu, India using geospatial techniques. Earth Sci Inform 12:211-223. https:// doi.org/10.1007/s12145-018-0363-5

Karimi H, Zeinivand H (2021) Integrating runoff map of a spatially distributed model and thematic layers for identifying potential rainwater harvesting suitability sites using GIS techniques. Geocarto Int 36:320-339

Kordestani MD, Naghibi SA, Hashemi H, Ahmadi K, Kalantar B, Pradhan B (2019) Groundwater potential mapping using a novel data-mining ensemble model. Hydrogeol J 27:211-224. https:// doi.org/10.1007/s10040-018-1848-5

Kwami IA, Ishaku JM, Mukkafa S, Haruna AI, Ankidawa BA (2019) Delineation of aquifer potential zones using hydraulic parameters in Gombe and environs. North-Eastern Nigeria Heliyon 5(7):01927

Lakshmi SV, Reddy YV (2018) Identification of groundwater potential zones using GIS and remote sensing. Int J Pure Appl Math 119:3195-3210

Lentswe GB, Molwalefhe L (2020) Delineation of potential groundwater recharge zones using analytic hierarchy process-guided GIS in the semi-arid Motloutse watershed, eastern Botswana. J Hydrol Reg Stud 28:100674

Nasir M, Khan S, Zahid H, Khan A (2018) Delineation of groundwater potential zones using GIS and multi influence factor (MIF) techniques: A study of district Swat, Khyber Pakhtunkhwa, Pakistan. Environ Earth Sci 77:367

Panahi MR, Mousavi SM, Rahimzadegan M (2017) Delineation of groundwater potential zones using remote sensing, GIS, and AHP technique in Tehran-Karaj plain Iran. Environ Earth Sci 76:792. https://doi.org/10.1007/s12665-017-7126-3

Qadir J, Bhat MS, Alam A (2020) Rashid, I. mapping groundwater potential zones using remote sensing and GIS approach in Jammu Himalaya. Jammu Kashmir Geoj 85:487-504

Saaty TL (1990) How to make a decision: the analytic hierarchy process. Eur J Oper Res 48:9-26

Saaty TL (2005) Theory and applications of the theory of the analytic network processes. Decision making with benefits, opportunities, costs, and risks. RWS Publications, Pittsburgh

Shao Z, Huq ME, Cai B, Altan O, Li Y (2020) Integrated remote sensing and GIS approach using fuzzy-AHP to delineate and identify groundwater potential zones in semi-arid Shanxi Province. Environ Model Softw 134:104868

Thapa R, Gupta S, Guin S, Kaur H (2017) Assessment of groundwater potential zones using multi-influencing factor (MIF) and GIS: a case study from Birbhum district, West Bengal. Appl Water Sci 7:4117-4131. https://doi.org/10.1007/s13201-017-0571-z

Yıldırım Ü (2021) Identification of groundwater potential zones using GIS and multi-criteria decision-making techniques: a case study upper Coruh River basin (NE Turkey). ISPRS Int J Geo-Inf 10(6):396. https://doi.org/10.3390/ijgi10060396

Zghibi A, Mirchi A, Msaddek MH, Merzougui A, Zouhri L, Taupin JD, Chekirbane A, Chenini I, Tarhouni J (2020) Using analytical hierarchy process and multi-influencing factors to map groundwater recharge zones in a semi-arid Mediterranean coastal aquifer. Wat 12:2525

Publisher's Note Springer Nature remains neutral with regard to jurisdictional claims in published maps and institutional affiliations. 